\title{
AUSTRALIAN OCEANS POLICY: IMPLICATIONS FOR MARINE ENVIRONMENTAL MANAGEMENT
}

\author{
by Bruce Davis
}

\begin{abstract}
DAvis, B., 2000 (31:v): Australian Oceans Policy: Implications for marine environmental management. In Banks, M.R. \& Brown, M.J. (Eds): TASMANIA AND THESOUTHERNOCEAN. Pap. Proc. R. Soc. Tasm. 133(3): 11-15.

https://doi.org/10.26749/rstpp.133.3.11 ISSN 0080-4703. Institute of Antarctic and Southern Ocean Studies, University of Tasmania, GPO Box 252-77, Hobart, Tasmania, Australia 7001.

Australia has one of the largest marine jurisdictions in the world. Attempts to develop an environmental management regime for this vast area were piecemeal until 1995, when it was announced an integrated oceans policy would be developed. Despite criticisms of process and content, the "Oceans Policy" released in December 1998 does provide a framework for resolving many maritime problems during the next decade.
\end{abstract}

Key Words: Australia, ocean, marine, environment, management, oceans policy.

\section{INTRODUCTION}

Australia has one of the largest and most diverse marine jurisdictions in theworld, fronting three oceans and involving a number of offshore island dependencies, plus a significant proportion of coastal Antarctica. Managing such a substantial area poses particular problems for a middle-power federalist nation, more orientated towards terrestrial issues than maritime problems. Apart from the logistical difficulty of surveillance and enforcement, there are substantial constitutional legislative and administrative obstacles, highly diverse stakeholder perceptions and sectoral interests, some data deficiencies and limited research and development capability (Davis 1995).

These complexities have not inhibited the Australian Government from attempting to develop a national framework for handling marine environmental problems. While the Canadians have approached the issue via a single overarching statute, the Australian approach has been to develop a comprehensive policy framework in which various levels of government and major community interests all have an important role to play. The key question is whether effective collaboration and partnership can be achieved. It is too early to form an informed judgement about this; the most that can be claimed is that a variety of initiatives are being actively pursued, but the available budgetary resources are thin and widely spread.

In order to understand how the Australian Oceans Policy announced by the Prime Minister on 23 December 1998 came to fruition and what its implications are, we must first consider the national and international context, as well as earlier, somewhat more fragmentary approaches, and final coalescence to a coherent policy framework.

\section{THE INTERNATIONAL CONTEXT}

Australia's ratification, on 5 October 1994, of the United Nations Convention on Law of the Sea (UNCLOS) brought Australia into direct participation in a universal law-making instrument of enormous importance (Shearer 1994) and very considerable scope (320 articles and nine technical annexes). In effect, the area of national jurisdiction was doubled in terms of rights to natural resources and regulation of various activities, but Australia also entered into a series of international obligations then shared by more than 60 nations and with the longer-term prospect of many other countries becoming actively involved. Contrary to public perception, the rights assigned do not grant unfettered sovereignty; Australia is obliged to recognise a diversity of guiding principles and operational arrangements for various oceanic zones and sectoral fields (Rothwell 1996). One must also recognise that the UNCLOS was mainly drafted prior to 1982; thus, there are other environmental and fisheries issues which have required subsequent negotiation, and not all are finally resolved (Miles 1997, Johnson, 1996).

The UNCLOS does not exist in isolation; Australia is a party to at least 80 other international treaties, conventions and agreements, as well as a number of bilateral arrangements, such as the Timor Gap Treaty (Kaye 1995). While each regime may have been negotiated on the basis of individual need, ad hoc creation has led to numerous overlaps whose impacts, whether beneficial, benign or dysfunctional, are not yet fully tested (Herr \& Chia 1995). There are few institutional instruments for harmonisation of these regimes, and the process of translating various international obligations into domestic practice (national statutes and policies) varies in speed and effectiveness from one country to the next (Kriwoken \& Cote 1996). There is also the intriguing question of how to treat nations which are not yet party to such agreement or may act as renegades to particular initiatives within the international system.

The most that can be claimed is that multilateral cooperation on marine environmental issues is rapidly increasing, and that a body of formal and customary international law is steadily being developed and consolidated (Sands 1993).

\section{THE AUSTRALIAN SITUATION PRE-1990}

The Australian Constitution makes no mention of the term "environment", but this has not prevented both the States and Commonwealth from enacting various pieces of legislation aimed at perceived needs in nature conservation 
and environmental management. In general, resource development, land-use planning, pollution prevention and protected areas management are the prerogative of the States and the Northern Territory, with the federal role limited to suasion towards common standards, research assistance and funding of diverse resource projects and programs (Davis 1991). Nonetheless, public opinion polls reveal a strong community expectation that the Commonwealth should take a leadership role and exercise reserve powers when circumstances dictate e.g. conservation of the Great Barrier Reef (Davis 1992). Moreover, international obligations place a responsibility on the Federal Government to ensure various international agreements are domestically implemented and provincial action meets specified criteria (Crommelin 1983, Zines 1985).

As the Oceans Policy Issues Paper (May 1998 Commonwealth of Australia [CoA] 1998b) notes, in the early 1970s the States challenged the Commonwealth's assertion of maritime sovereignty under the Seas and Submerged Lands Act 1973. The High Court upheld federal jurisdiction to high-water mark, but in practical terms it was essential to grant the States some room for manoeuvre in respect of near-coastal waters (Haward 1989). A series of arrangements wete entered into, giving the States and the Northern Territory title to three miles of territorial sea, subject to various conditions relating to security and other matters, the ensuing legislation entering into force in February 1982. Known as the Offshore Constitutional Settlement (OCS), the modus vivendii was not really offshore, nor constitutional nor a settlement, there being several subsequent skirmishes between States and the States and the Commonwealth, especially with respect to offshore energy resources and fisheries problems (Haward 1992).

Federal action on marine environmental management had actually commenced in the 1960s, mainly with regard to limited and specific issues, such as marine pollution and the dumping of wastes. Australia became a party to a number of IMO (International Maritime Organisation) sponsored international agreements, such as the London Dumping Convention 1972 and MARPOL 73/78, the latter dealing with ship-sourced marine pollution. Other significant domestic initiatives included establishment of the Great Barrier Reef Marine Park 1975, the 1979 declaration of a 200 nautical mile Australian Fishing Zone (AFZ) and the Australian Government's key role in development of the Convention on the Conservation of Antarctic Marine Living Resources (CCAMLR), which entered into force in 1982. Inshore, all levels of government produced reports on fisheries problems and the need for improved coastal management, but these were rarely acted upon, given resistance from sectoral interests and lack of effective statutory authority or funding (Nguyen 1997). Numerous parliamentary reports noted such deficiencies, but were largely ignored, given the salience of other political issues (Haward 1996).

\section{NEW DIRECTIONS, THE EARLY $1990 \mathrm{~S}$}

During the early 1990 s increased attention began to be given to marine environmental management. The catalyst, in part, was preparations for the 1992 United Nations Conference on Environment and Development (UNCED), but also criticism from a wide range of commentators about the fragmented character of Australian maritime activity and research (Bergin 1986, AIMS 1988, HOMA 1993, McKinnon 1993). The initial response was a statement by the then Prime Minister (the Hon. R.J. Hawke MP) in July 1989 , referring a coastal zone inquiry to the Resource Assessment Commission (RAC), notwithstanding the fact that more than 60 coastal reports had been compiled from the 1960s onwards. Still, there were other initiatives, some of which are briefly summarised below.

- May 1992: An Intergovernmental Agreement on Environment was announced, aimed at improved collaboration between the States and the Commonwealth on environmental issues.

- December 1992: Release of a national policy on Ecology Sustainable Development (ESD).

- August 1993: Announcement of an Ocean Rescue 2000 package, subsequently expanded to include the following elements:

- an Australian marine conservation plan;

- a national representative system of marine protected areas;

- preparation of a "state of the marine environment" report;

- a national marine information system;

- a national marine education program; and

- the establishment of a Marine and Coastal Community network.

Impressive as this may appear, funding was thin and some elements are still being developed today.

- November 1993: Release of the Resource Assessment Commission's Coastal Zone Inquiry: Final Report (Resource Assessment Commission 1993). This recommended establishment of a national coastal action program, a coastal resources management Act and a national coastal management agency, the latter two proposals being ignored.

The Commonwealth did subsequently announce funding of a Coastcare Program, but took considerable time to develop the institutional arrangements essential to provide holistic and integrated action.

- 1993: The McKinnon report Review of Marine Research Organisation (McKinnon 1993) subsequently led to establishment of a Marine Industries and Science Council, but a development strategy did not appear until April 1996.

- 1994: The Australian Committee for IUCN (the World Conservation Union) produced a Strategy for Conservation of Australia's Marine Environment (Aust. Comm. IUCN 1994) and followed this up in March 1998 with a discussion paper on Conserving Australia's Oceans (Aust. Comm. IUCN 1998).

- 1995: Release of the first State of Marine Environment Report (SOMER) (CoA 1995), which provided an initial baseline, but highlighted five major concerns about the Australian marine environment, namely: 
decl ining marine and coastal water quality, particularly an outcome of inappropriate catchment land-use practices

- loss of marine and coastal habitat;

- unsustinable exploitation of some marine and coastal resources;

- lack of integrated marine science policy; and

- negleci of long-term monitoring of the marine environment.

- 1995: Release of the joint CSIRO/AGSO/AIMS report Ocean Ortlook: A Blueprint for the Future (Sci. Program Steering Comm. 1995). This document attempted to bridge the gap between scientists and managers, by identifying needs and opportunities for collaborative action, as well as outlining a research strategy for the future.

There are two observations one can make about these diverse initiatives: first, welcome as they were, most were ad hoc in character and neglected essential institutional needs in a field where vested interests and sectoral administration prevailed; second, a major opportunity was lost when Australia announced it would become a signatory to the UNCLOS in August 1994, the Convention entering into force in November that year. This was a time when community and political attention could have been captured about oceanic issues, but the Commonwealth announcement was little more than a normal press release.

Critics were quick to point out the need for more positive federal leadership, but the reluctant response from Prime Minister Paul Keating, in December 1995, was that an Australian Oceans Policy would eventually be developed, with no timeline or details specified. The only clue provided was a claim the policy would be based on sustainable use of resources, while conserving their biological viability. This rather tentative approach to oceanic issues may be attributable to preoccupation with terrestrial problems such as dryland salinity and water quality; Australian politicians were not yet attuned to a marine agenda.

\section{THE OCEANS POLICY INITIATIVE 1995-98}

This is not the place to detail the process by which a number of issue papers and consultancy reports were commissioned by Environment Australia and published in late 1997, apart from noting that a somewhat selective consultation process was involved and excessive reliance continued to be placed on assumed Commonwealth-State cooperation, which had not proven markedly effective in the past (Davis 1995). One positive achievement was that a wide range of marine environmental problems were addressed, the international context was noted and a number of marine planning models were analysed, as well as some management options. These documents provided a reasonably sound basis for national policy development, as long as some procedural and institutional difficulties could be overcome.

When the final overview Issues Paper (CoA 1998b) was released for public comment in May 1998, it effectively explained the need and aims of national oceans policy, stressing the need for a form of management which was ecosystem based, with sound scientific information, but it gave no details of intended priorities, anticipated outcomes or resourcing implications. While there was an environmental flavour to the report, many strategic, diplomatic, intergovernmental and conflict mediation aspects were entirely overlooked (Bateman 1997). In brief, this was somewhat thin treatment of rather complex and contentious matters, lacking vision or a clear plan of action. A starting point, but once again a great opportunity missed to move from piecemeal approaches towards more integrated strategy.

The term "marine environmental management" was not clearly defined in any of the discussion documents, although it was feasible to construe some perceived needs and guiding principles in individual issue papers. Section 2 of the Issues Paper (CoA 1998b) for example does identify elements of ecologically sustainable oceans management in terms of some planning provisions:

- planning for ecosystem health, but recognising the need for multiple use of resources;

- adopting a precautionary approach by recognising risk and uncertainty;

- noting the value of user-pays and other forms of economic instruments;

- the need to build collective community stewardship and provide transparency of decision-making;

- fostering ecologically sustainable resource use in all marine industries.

Underpinning all of this was recognition of the need to strengthen some sectoral capacities while pursuing more coordinated administrative action.

A valuable contribution to this debate was provided by the Report of the Ministerial Advisory Group on oceans policy, published in March 1998 (CoA 1998a). The collective opinions exposed, whether in agreement or disagreement, highlighted some of the problems to be encountered and overcome if an effective oceans policy was to be formulated and implemented. While recognising the need for sound scientific information, the Advisory Group was emphatic that strong Commonwealth leadership was required and that a variety of organisational difficulties needed to be overcome, including some jurisdictional questions and improved sectoral cooperation.

Without canvassing the nearly 100 recommendations made by the Advisory Group, some key concerns and proposals can be highlighted:

- understanding of marine ecosystems should be further developed;

- implementation of a National Representative System of Marine Protected Areas should be accelerated;

- State and Commonwealth legislative frameworks should be reviewed to ensure habitat protection and conservation of endangered marine species;

- the Commonwealth should adopt a leadership role in addressing land-sourced marine pollution;

- consideration should be given to tradeable rights in marine fisheries, but fisheries should be managed on an ecosystem and ESD basis;

- further research is required into aquaculture related issues;

- suggestions for improving the National Plans to combat oil pollution, deal with ballast water and combat introduced species should be considered;

- government-industry collaboration should be improved in research and management of offshore energy resources; 
- urgent priority should be given to analysis and strategic planning of the marine tourism industry, since knowledge of its environmental impacts is poorly charted;

- indigenous communities should be widely consulted and actively involved in marine management;

- there should be increased integration of efforts in marine surveillance and enforcement; and

- the numbers, skills mix and training of individuals involved in oceans management and governance should be improved.

Some of these propositions were paralleled in a discussion paper prepared by the Australian Committee of IUCN (the World Conservation Union) released in March 1998, entitled Conserving Australia's Oceans (Australian Committee of IUCN 1998).

\section{THE AUSTRALIAN OCEANS POLICY, DECEMBER 1998}

When the final version of the Oceans Policy was announced by Prime Minister John Howard on 23 December 1998, it largely mirrored the content of the earlier Issues Paper, but had been fine-tuned to provide a little more detail. Two documents were released (CoA 1998c), the first dealing with contextual matters, the integrated and ecosystem-based approach, guiding principles, but also some key initial actions. The second document details specific sectoral measures, the need for public participation and performance evaluation. Overall these proposals were more positive and comprehensive than some critics had expected, particularly as they were sweetened by announcement of a $\$ 50$ million allocation over three years for a range of actions associated with its implementation.

The Oceans Policy statement drew attention to the immense scale of Australia's Exclusive Economic Zone (EEZ) and the reality that Australia was the first nation to develop such a comprehensive framework for oceanic environmental management. Among the initial key actions to be undertaken were the following:

- development of marine regional plans, beginning with the southeastern region of the EEZ;

- strengthening baseline environmental surveys, sustainability indicators and monitoring programs;

- support for the development of a single national ballast water management system;

- creation of a nationally representative system of marine protected areas;

- measures to improve the sustainability of Australian fisheries, including improved effectiveness in preventing illegal fishing; and

- trials to treat some problems of land-sourced marine poliution.

In general these measures were well received and some are already being acted upon; nonetheless the overall picture remains one of a series of individually tailored programs rather than a cohesive whole. Perhaps this is inherent, given the diversity of interests and institutions involved and the necessity to negotiate a variety of agreements between the States, Territories and Commonwealth.
Facilitation and cooperation may be engendered by a new federal agency, the National Oceans Office, which was announced in August 1999. A National Oceans Advisory Group has also been established, but its influence is largely dependent upon whether the Federal Minister for Environment is prepared to take its advice. Commonwealth-State cooperation may be engendered through bodies such as ANZECC (the ministerial Australian and New Zealand Environment and Conservation Council), but its role in the past has largely been to set common standards rather than strategic direction. Whether the latter will be achieved in the oceans policy area remains to be seen.

\section{IMPLICATIONS AND FORWARD AGENDA}

Commentators on the maritime agenda are pleased that release of the Oceans Policy statement has initiated a new regime, but critics are mindful of the reality that in the past competition between the Australian States for economic development has led to attrition of natural resources (Toyne 1994). The forward agenda does contain a number of interesting challenges:

- the current policy says little about Australia's role in international marine environmental management;

- there is a significant loss of coastal and marine habitat and many Australian fisheries are under sustainability threat;

- almost 70\% of marine pollution arises from land-sourced origins and no government has yet seriously contemplated how this terrestrial-marine dilemma should be administratively handled;

- there is a serious threat from introduced marine species which are proving costly and difficult to eradicate; and

- given Australia's immense coastline, it is difficult to devise remedial plans to deal with critical incidents, such as oilspills or illegal incursions by foreign fishermen or clandestine immigrants.

In addition to the above there is a new and indeterminate factor, namely advent of the Environment Protection and Biodiversity Conservation Act (Cth) 1999, which was passed with remarkably little parliamentary debate, despite its complexity and powerful implications. In theory, the new statute limits Commonwealth environmental action to six fields of "national significance", including Federal offshore areas, but leaves many matters to the discretion of the Minister and involves negotiated agreements with the States and Territories. Many aspects of implementation remain to be specified and tested.

If one considers the Oceans Policy statement in isolation, it correctly adopts a proactive rather than reactive approach. The agenda is immense, the resources are limited; thus collective ownership must be fostered. This is the central challenge in rendering the Oceans Policy operational, during the first decade of the third millennium. 


\section{REFERENCES}

Official p ublications and reports

Commonweltith of Australia, 1995: STATE OF MARINE ENYIRONMENT REPORT (SOMER). Environment Ausiralia, Canberra.

COMMONWELLTH OF AUSTRALIA, 1998a (March): AUSTRALIA'S OCEANS POLICY: REPORT OF THE MINISTERIAL ADVISORY GROUP. Environment Australia, Canberra.

COMMONWELLTH OF Australia, 1998b (May): AUSTRALIA'S OCEANS POLICY - AN ISSUES PAPER. Environment Ausiralia, Canberra.

CommonWealth of Australia, 1998c (December): AUSTRALIA'S OCEANS POLICY. Environment Australia, Canberra.

Commonwealth of Australia, 1998d: REFOrM OF COMMONWEALTH ENVIRONMENT LEGISLATION: CONSULTATION PAPER. Issued by Senator R. Hill, Commonwealth Minister for Environment, Canberra.

homa (Heads of Marine Agencies), 1993: REPORT ON STATUS OF MARINE SCIENCE AND TECHNOLOGY. Canberra.

Resource AsSessment COMmission, 1993: COASTAL ZONE INQUIRY: FINAL REPORT. Canberra.

United Nations 1982, 1984: CONVENTION ON LAW OF THE SEA. Reprint by Platzoder, R. (Ed.), 1995. Martinus Nijhoff, Dordrecht.

\section{Other references}

aims (Australian Institute of Marine Science), 1998 (27 June): "Coordinating Australia's maritime policies". Letter to Prime Minister.

AUSTRALIAN COMMITTEE FOR IUCN, 1994: A STRATEGY FOR CONSERVATION OF AUSTRALIA'S MARINE ENVIRONMENT. Sydney.

Australlan Committee fOr IUCN, 1998: CONSERVING AUSTRALIA'S OCEANS. Occ. Pap. 7. Sydney.

BATEMAN, S., 1997: The development of Australia's oceans policy: Implications for marine environmental law and policy. Paper for the ACEL Environmental Outlook Conference, October, Sydney.

Bergin, A., 1986: Australian ocean policy: The need for a comprehensive review. Mar. Policy 10(2): 155-158.

Crommelin, M., I983: RESOURCES LAW AND PUBLIC POLICY. Paper 59. Centre for Research on Federal Financial Relations, Australian National University.

DAvIs, B., 1991: Environmental management. In Galligan, B., Hughes, O. \& Walsh, C. (Eds): INTERGOVERNMENTAL RELATIONS AND PUBLIC POLICY. Allen \& Unwin, Sydney: 146-162.

Davis, B., 1992: Federal-State tensions in Australian environmental management: The world heritage issue. In Walker, K. (Ed.): AUSTRALIAN ENVIRONMENTAL POLICY. New South Wales University Press, Sydney: 215-232.

Davis, B., 1995: Re-inventing offshore Australia: Oceans Policy in the Post-UNCED Era. Aust. Geogr. 26(1): 38-44.

Haward, M., 1989: The Australian Offshore Constitutional Settlement. Mar. Policy 13(4): 334-348.

HaWARD, M., 1992: Federalism and the Offshore Constitutional Settlement. Unpubl. PhD thesis, Univ. Tasm., Hobart.
HaWARD, M., 1996: The institutional framework for Australian ocean and coastal management. Ocean Coastal Manage. 33(1-3): 19-40.

Herr, R. \& ChIA, E., 1955: The concept of regime overlap: Towards identification and assessment. In Davis, B. (Ed.): OVERLAPPING MARITIME REGIMES: AN INITIAL RECONNAISSANCE. Monograph 2. Antarctic CRC, Univ. Tasm., Hobart.

Johnson, D., 1996: Unclos III and UNCED: A collision of mindsets. In Kriwoken, L., Haward, M., Vander Zwaag, D. \& Davis, B. (Eds): OCEANS LAW AND POLICYIN THE POST UNCED ERA: AUSTRALIAN AND CANADIAN PERSPECTIVES. Kluwer, London: 11-24.

KAYE, S., 1995: AUSTRALIA'S MARITIME BOUNDARIES. Wollongong Pap. Mar. Policy 4. Centre for Maritime Policy, University of Wollongong.

KRIwOKen, L. \& COTE, R., 1996: Development in Australian and Canadian environmental management. In Kriwoken, L., Haward, M., Vander Zwaag, D. \& Davis, B. (Eds): OCEANS LAW AND POLICY IN THE POST UNCED ERA: AUSTRALIAN AND CANADIAN PERSPECTIVES. Kluwer, London: 215-242.

MCKinNon, K., 1993: REVIEW OF MARINE RESEARCH ORGANISATION. University of Wollongong. (Prepared for Commonwealth Department of Science and Technology.)

McKinnon, K.R., Hammond, L.S., Hickman, B., Lamberton, D., Male, R., Taylor, A.R., Thomson, J.M. \& Williams, M., 1989: OCEANS OF WEALTH? A report by the Review Committee on Marine Industries, Science and Technology. AGPS, Canberra.

Miles, E., 1997: The approaches to UNCLOS and Agenda $21-$ A synthes1s. In Kusuma-Atmadja, M., Mensah, T. \& Oxman, B. (Eds): SUSTAINABLE DEVELOPMENT AND PRESERVATION OF THE OCEANS. Law of the Sea Institute, University of Hawaii: 16-42.

NGUYEN, T., 1997: The application of integrated management to coastal and marine environments with case studies from Australia and Tasmania. Unpubl. Masters thesis, Univ. Tasm., Hobart.

RoTHWELL, D., 1996: The legal framework for Australian ocean and coastal management. Ocean Coastal Manage. 33(13): $41-62$.

SANDS, P. (Ed.), 1933: GREENING INTERNATIONAL LAW. Earthscan Publications, London.

Scientific Program Steering Committee, 1995: OCEAN OUTLOOK: A BLUEPRINT FOR THE OCEANS. Report of a Congress, November 1994. CSIRO/AGSO/AIMS, Canberra.

Shearer, I., 1994: The EEZ: Implications for national and international marine industries and sectors. Paper presented at the Oceans Outlook Conference, November, Canberra.

TOYNE, P., 1994: THE RELUCTANT NATION. ABC Books, Sydney.

ZINES, L., 1985: The environment and constitution. In Mathews, R.L. (Ed.): FEDERALISM AND THE ENVIRONMENT. Centre for Research on Federal Financial Relations, Australian National University, Canberra.

(accepted 16 November 1999) 